seldom keen to attend meetings with the commission on research issues.

Yet their support is essential if there is to be any increase in international funding for such work. There is no increase in the money earmarked for the Third World in the EU's new fifth Framework programme of research, even though the ECU250 million handled in the fourth Framework programme is generally considered to have been well spent.

Equal partnerships and the potential for building up local research capacity in the South became mandatory components of all projects funded through the EU's INCO-DC (International Coordination - Developing Countries) programme.

In one project, for example, scientists from France, Britain, Kenya and Brazil collaborated on a study of the genetic component of susceptibility to schistosomiasis. This involved epidemiological studies, mapping of susceptibility genes and the evaluation of immunological correlates of disease.

The study required the creation of an immunology research group at the Faculty of Medicine of Uberaba, Brazil, and strengthening the schistosomiasis research group at the Federal University of Bahia, Brazil.

INCO-DC applies the same rules to its approval of projects as other EU research programmes, emphasizing the need for scientific excellence and eschewing any sense of offering 'charity'. "You don't do anyone any favours by funding second-rate research with second-rate equipment," says a programme spokesman. "Scientists in the South must be supported only to do research at the same standards as in Europe."

EU member states have been adopting the same new philosophy in their national programmes. Denmark, Europe's largest aid donor in relation to its gross national product (GNP), has in the past ten years increased the proportion of its aid budget spent on research nearly fivefold, to three per cent of the total.

One exception to the EU trend is Britain, which devotes only 0.27 per cent of its GNP to development, four times less than Denmark in relative terms, although it spends around seven per cent of this on "research and related knowledge generating activities". Poverty eradication is the main development priority but it "sees continued investment in knowledge generation as a key element in achieving its aims and objectives for international development".

Britain has shown that such philosophical statements can be backed with cash. Last summer, for example, Prime Minister Tony Blair announced to the meeting in Birmingham of the G8 group of industrialized countries that Britain planned to spend $£ 60$ million (US\$100 million) to support the international Multilateral Initiative on Malaria (see Nature 388, 219; 1997).

Alison Abbott

\section{Technology and tradition clash in India}

[NEWDEHI] When India's first waste incineration plant, designed to generate $4 \mathrm{MW}$ of electricity

by burning 300 tonnes of rubbish daily, was commissioned in New Delhi in 1988, officials billed it as the technological solution to the problem created by mountains of municipal waste.

Such plants were to be built nationwide. It was therefore a surprise when the plant closed down in 1992, after remaining idle for four years, and without having produced any electricity (see Nature 359, 763; 1992).

The reason was straightforward: neither the government nor the Danish contractor had considered Delhi's 8,000 rag pickers, who systematically retrieve reusable items such as wood, plastics and cloth from municipal landfill sites. Once such combustible materials were removed, the remains - mostly rotten vegetables and unburnable cooking wastes were insufficient to operate the plant.

"We have learnt that technology by itself cannot solve our society's problems," says Valangiman Ramamurthi, secretary to the Department of Science and Technology (DST). "Science-based innovation has little role in development unless it is socially accepted and fits into the prevailing cultural system."

India's social and cultural diversity also means that what is welcomed by one group may be resented by another. Piped water has been a boon to the people of Tamilnadu, but, according to Ramamurthi, young women in rural Rajasthan found the water taps a threat to social freedom, and smashed them up.

Before the taps were installed, the girls fetched water from distant sources, and the long daily walks gave them a chance to socialize with men. As well as spoiling their love life the taps added to their drudgery at home, because their mothers, finding that the girls had free time, made them do extra work.

Equally frustrating for Indian researchers has been their years of effort to improve the cycle rickshaw, the primary mode of transport for millions of Indians since its introduction in 1930. A motorized version introduced in the late 1970 s never really caught on, as rickshaw pullers became concerned about the need to maintain the motor and the hassles of getting a driving licence.

A similar fate befell a cycle rickshaw fitted with a 'regenerative' braking system (pictured), in which the energy lost in braking was stored in a bank of springs and released when the vehicle was ready to move again. Amitabha Ghosh, the inventor of the device - and now director of the Indian Institute of Technology in Kharagpur - says rickshaws fitted with this system "required 44 per cent less pedalling force during start-ups, besides reducing the energy expended by pullers by 38 per cent".

Despite this advantage, the design has

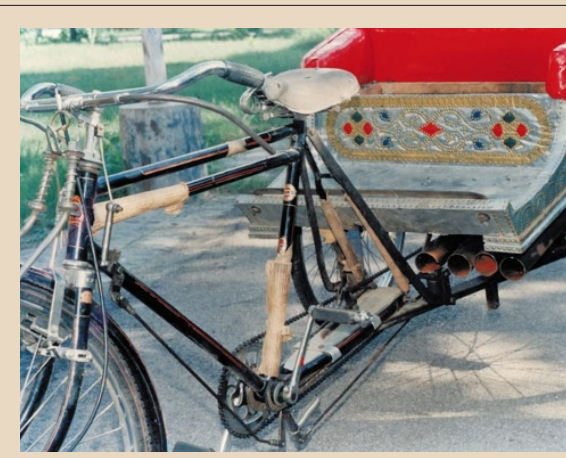

Inappropriate technology: 'regenerative' brakes on rickshaws ignored the cost of retrofitting

failed to win converts. The main reason, says Ghosh, is that few pullers own the rickshaw they rent them. "Owners have no motivation for spending $\$ 60$ for retrofitting, and have no concern for the health of the pullers, as there is no shortage of poor people in search of an income."

The DST's more recent effort to introduce another versatile design also met with resistance from cycle rickshaw owners in Agra who, fearing competition, smashed up the two vehicles sent for a demonstration.

'Taraloom', an improved hand loom developed with money from the DST, is another example of how a technological innovation, despite its advantages, can fail to have an economic impact unless it is affordable. The rugged steel loom with a flywheel attachment for high-speed operation means weavers can increase output by 60 per cent.

But the 15,000 rupees (US $\$ 354$ ) price is beyond the reach of millions of poor weavers who work at home on wooden hand looms passed down through generations. In the past eight years, only 20,000 Taralooms have been sold, mostly to cooperatives. "Cost is just one factor," admits Sanjay Sharma, inventor of Taraloom. "The important barrier is tradition."

'Modernity' is also being put to the test at Agra, where the Taj Mahal's white marble has turned yellowish due to sulphur dioxide pollution from the 170 coal-fired foundries nearby. "Twenty-five years ago we offered to replace their traditional furnaces with gas-fired ones but they refused," says P. Ramachandra Rao, director of the National Metallurgical Laboratory (NML) in Jamshedpur.

Now the foundries have been ordered to adopt NML technology by the supreme court Rao says that the $\$ 30,000$ cost of a gas-fired cupola is the main reason for the foundries' opposition. But commercial sources admit that the foundries are resisting natural gas because of the reduced opportunities for tax evasion. Unlike coal, natural gas is supplied by the government and metered. Production figures can be worked out from gas consumed, and tax levied.

K.S.Jayaraman 